\title{
EMPLOYEES ENVIRONMENTAL PERFORMANCE BASED ON CONSCIENTIOUSNESS, AGREEABLESNESS, NEUROTICISM, OPENNESS, AND EXTRAVERSION
}

\author{
Nadiroh $^{1}$, Endah Setyaningrum ${ }^{2}$ \\ ${ }^{1}$ Fakultas Ilmu Sosial Universitas Negeri Jakarta, \\ Komplek Universitas Negeri Jakarta Gedung M. Hatta Jl. Rawamangun Muka, \\ Jakarta Timur, Indonesia 13220 \\ Orchid Id: 0000-0001-9807-2536, Sinta ID: 6003834 \\ Email:nadiroh@unj.ac.id \\ ${ }^{2}$ FMIPA Universitas Lampung, Bandar Lampung \\ Email: endahsetyanigrum375@gmail.com
}

\begin{abstract}
This research aims to determine the relationship between the big five personality factor (conscientiousness, agreeableness, neuroticism, openness, and extraversion) with an employee's environmental performance on employees at Jakarta Industrial Park (EJIP) Cikarang Company. The method used is quantitative method with a correlation technique. The research was conducted from November 2016 to March 2016, with a total sample of 85 people. Analysis of Variance (ANOVA) showed association between conscientiousness, agreeableness, neuroticism, openness, and extraversion with an employee's environmental performance, as calculated $F$ value of 4.02 to the level of sig. of .01, where the figure is much lower than the level of sig. .05. These result indicate that conscientiousness, agreeableness, neuroticism, openness, and extraversion significantly affect the employee's environmental performance.
\end{abstract}

Keyword: conscientiousness, agreeableness, neuroticism, openness, extraversion, and employee's environmental performance

\section{PENDAHULUAN}

Employee's

environmental

performance dibutuhkan dalam rangka peningkatan perilaku karyawan mengenai dampak lingkungan hidup yang dapat berkontribusi positif dan negatif dalam pencapaian tujuan organisasi/ perusahaan.
Kinerja lingkungan perusahaan didasarkan pada tanggapan permasalahan lingkungan bagi pihak manajemen yakni seperti bagaimana tindakan manajemen dalam proses penggunaan sumber daya alam secara efisien dan efektif. 
Perusahaan sendiri sering dihadapkan dengan banyak prioritas yang harus dilakukan, disatu sisi untuk persaingan bisnis dan disisi lain untuk perhatian kepada lingkungan alam. Peningkatan kinerja karyawan yang di barengi dengan peningkatan personality

(conscientiousness, agreeableness, neuroticism, openness, and extraversion) terhadap lingkungan, diharapkan dapat meminimalisir kerusakan lingkungan hidup.

Senada dengan yang dikemukakan oleh Jing Zhang (2014:19-28), bahwa dengan terjadinya fenomena perubahan iklim (climate change) sudah merupakan isu global yang menyebabkan berbagai resiko terhadap sistem lingkungan (natural system) dan manusia (social system). Hal ini akan diperparah oleh seiring peningkatan kegiatan manusia.

Organisasi juga berkontribusi yang signifikan dalam perubahan iklim. Dengan demikian perlu adanya kinerja lingkungan karyawan (employee's environmental performance) dalam meningkatkan kesadaran bagi tiap organisasi untuk berkontribusi nyata dalam meminimalisir kerusakan lingkungan yang terjadi.
Adapun penelitian terdahulu sebagai acuan dari penelitian yang dilakukan oleh peneliti adalah oleh Pascal Paile, Yang Chen, Olivier Boiral and Jiafie Jin (2013:1-82). Hasil penelitian, bahwa kinerja lingkungan sendiri dapat dievaluasi dengan menetapkan indikator seperti pencegahan polusi, minimalisasi limbah, kegiatan daur ulang, dan lain sebagainya. Selanjutnya, penelitian oleh Bakker, Tims dan Derks (2012:13601361), menyatakan bahwa beberapa penelitian telah mengungkapkan kepribadian positif pada karyawan menunjukkan kinerja pekerjaan yang baik pula.

Adapun perbedaan dalam penelitian ini adalah meneliti tentang employees' environmental performance yang dihubungkan dengan big five personality factor (conscientiousness, agreeableness, neuroticism, openness, and extraversion).

Colquitt, et.al (2017) mengatakan bahwa, “employees' environmental performance is value of a set of employee's behavior related to how they perceive in contributing positively toward their desire to preserve the environment". Jadi kinerja lingkungan karyawan 
merupakan nilai dari serangkaian perilaku karyawan yang berhubungan dengan bagaimana mereka memandang dalam memberikan kontribusi positif terhadap keinginan mereka untuk melestarikan lingkungan.

Ahmad, Ather dan Hussain (2014:572-574) sendiri ciri-ciri kepribadian dapat dipahami sebagai deskripsi dari seseorang berdasarkan faktor kejiwaan (psikologis) yang berbeda-beda tingkatnya. Ada lima kajian dasar yakni big five personality, yakni Conscientiousness,

Extraversion, Neuroticism, Agreeables dan Opennes.

Menurut Ivancevich, Konopaske \& Matteson (2008:75) bahwa, "Conscientiousness is exhibited by those who described asdependable, organized, thorough, and responsible”. Kesungguhan adalah kecenderungan seseorang untuk dapat diandalkan, terorganisir, menyeluruh dan bertanggungjawab. Individu yang memiliki tingkat kesungguhan yang tinggi cenderung tekun, bekerja keras, senang mencapai dan menyelesaikan berbagai hal. Sedangkan yang memiliki tingkat kesungguhan yang rendah cenderung jorok, ceroboh, tidak efisien dan bahkan malas. Dengan demikian sintesa Conscientiousness (kesungguhan) adalah kecenderungan seseorang untuk bertanggung jawab dan dapat diandalkan.

Menurut Colquitt, LePine dan Wesson (2017:298) bahwa, “Agreeableness people are warm, kind, cooperative, symphatetic, helful, and courteous". Keramahan yaitu orang yang menyenangkan, hangat, baik hati, kerjasama, penolong, simpati, dan sopan. Orang yang memprioritaskan perjuangan persekutuan, yang mencerminkan keinginan yang kuat untuk dapat diterima dalam hubungan pribadi sebagai sarana mengekspresikan kepribadian.

Sedangkan menurut Ivancevich, Konopaske \& Matteson (2014:75) mengatakan, "Agreeableness it is the tendency to be courteous, forgiving, tolerant, trusting, and softhearted." Keramahan adalah kecenderungan seseorang untuk memiliki rasa hormat, pemaaf, toleran, mudah percaya, dan berhati lunak.

Menurut Luthans (2008:77), “ciri utama keramahan adalah kooperatif, hangat, perhatian, sopan, dan dapat dipercaya." Suka bekerja sama, simpatik, suka menolong, santun, dan hangat adalah kepribadian yang agreebleness. Jadi 
sintesa agreeableness (keramahan) adalah kecenderungan seseorang memprioritaskan perjuangan persekutuan, yang mencerminkan keinginan yang kuat untuk dapat diterima dalam hubungan pribadi sebagai sarana mengekspresikan kepribadian.

Menurut Ivancevich, Konopaske \& Matteson (2014:75) bahwa, Emotional Stability is the tendency to experience positive emotional states, such as feeling psychologically secure, calm, and relaxed." Stabilitas Emosi adalah kecenderungan seseorang mengalami keadaan emosi yang positif seperti merasa aman secara psikologis tenang dan santai.

Colquitt, LePine dan Wesson (2017:298) mengatakan "neurotic people are nervous, moody, emotional, insecure, and jealous". Orang yang Neuroticism adalah orang yang gelisah, gugup, murung, emosional, tidak aman, dan cemburu. Lebih tegas dikatakan orang neurotik adalah "orang yang cenderung kurang bahagia dalam kehidupan mereka. Individu yang memiliki kepribadian neurotisme yang rendah cenderung mengalami stabilitas emosi" (Colquitt, et.al, 2017:301).
Luthans (2008:77) mengatakan, "core traits emotional stability is calm, secure, happy, and unworried." Neuroticism merupakan tipe kepribadian yang cenderung gugup, murung, cemburu, emosional, waspada, dan mudah tersinggung. Jadi sintesa neuroticism (stabilitas emosi) adalah kecenderungan seseorang mengalami emosi yang positif yang tenang, santai dan aman.

Berdasarkan pendapat Ivancevich, Konopaske \& Matteson (2014:75) bahwa, "Opennes to experience this dimension reflects the extent to which an individual has broad interests and is willing to take risks." Keterbukaan terhadap pengalaman adalah kecenderungan individu untuk merefleksikan sejauh mana individu memiliki minat yang luas dan bersedia mengambil resiko.

Colquitt, LePine dan Wesson (2017:304) berpendapat, “open people are curius, imaginative, creative, complex, refined, and sophisticated." Keterbukaan terhadap pengalaman adalah orang yang ingin tahu, imajinatif, kreatif, rumit, halus dan moderen. Dengan demikian sintesa keterbukaan terhadap pengalaman adalah kecenderungan seseorang untuk merefleksikan sejauh mana individu 
memiliki minat yang luas terhadap hal-hal yang baru.

Menurut pendapat Colquitt, et.al., (2017:298) bahwa, “Extraverted people are talkative, sociable, passionate, assertive, bold an dominant”. Ekstraversi adalah orang yang banyak bicara, ramah, semangat/penuh kasih, tegas, berani, dan dominan. Sedangkan menurut Ivancevich, Konopaske dan Matteson (2014:75) bahwa, "Ekstraversion refers to the tendency to be sociable, gregarious, assertive, talkative, and active". Ekstraversi mengacu pada kecenderungan orang untuk bersosialisasi, tegas, suka berteman, suka berbicara, dan aktif. Jadi sintesa ekstraversi adalah kecenderungan seseorang untuk bersosialisasi memperioritaskan, memperjuangkan status, dan berkeinginan yang kuat dan berpengaruh dalam struktur sosial sebagai sarana untuk mengekspresikan kepribadian.

Berdasarkan uraian tersebut, peneliti tertarik untuk mengadakan penelitian hubungan antara conscientiousness, agreeableness, neuroticism, openness, dan extraversion dengan kinerja lingkungan karyawan (employee's environmental performance), studi korelasional pada karyawan di Perusahaan East Jakarta Industrial Park (EJIP) Cikarang Tahun 2016.

\section{METODOLOGI}

Metode yang digunakan dalam penelitian ini adalah metode kuantitatif dengan teknik korelasional. Penelitian ini berkaitan dengan pengumpulan data untuk menentukan ada atau tidaknya hubungan antara variabel conscientiousness, agreeableness, neuroticism, openness, dan extraversion dengan employee's environmental performance, serta mengukur seberapa besar kekuatan hubungan tersebut (koefisien korelasi).

\section{HASIL DAN PEMBAHASAN}

\section{Hubungan antara conscientiousness dengan employee's environmental performance}

Hubungan antara conscientiousness dengan employee's environmental performance dilakukan dengan menggunakan analisis regresi sederhana. Hasil analisis regresi tersebut berupa persamaan $\hat{Y}=95,155+0,960 \mathrm{X}_{1}$. Adapun uji signifikansi dan linearitas model regresi tersebut terdapat pada tabel 1 berikut ini: 
Tabel 1.

ANAVA untuk Uji Signifikansi dan Linearitas Model Regresi $\hat{Y}=95,155+0,960 X_{1}$

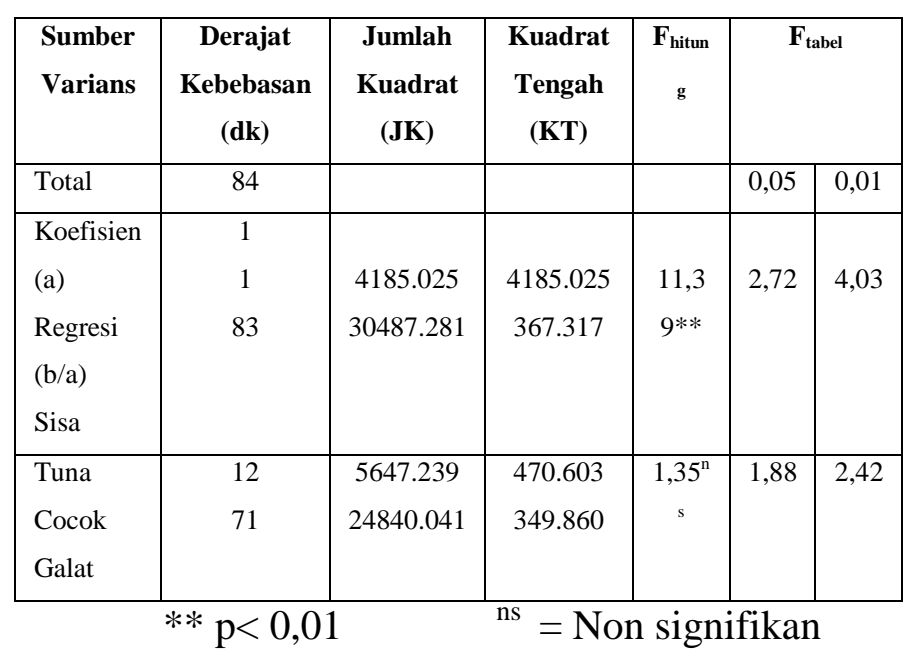

Pada tabel di atas nampak ada hubungan yang sangat signifikan antara conscientiousness dengan employee's, environmental performance $(\mathrm{p}<0.01)$ dan hubungan tersebut (regresi $\hat{\mathrm{Y}}=95,155+$ $\left.0,960 \mathrm{X}_{1}\right)$ adalah linier.

Hal tersebut menunjukkan conscientiousness makin tinggi, maka employee's environmental performance juga akan semakin tinggi.

Tabel 2.

Uji Keberartian Koefisien Korelasi Parsial $\left(\mathrm{r}_{\mathrm{y} 1.2345}\right)$

\begin{tabular}{|c|c|c|c|c|c|}
\hline $\begin{array}{c}\text { Sampel } \\
(\mathbf{n})\end{array}$ & $\begin{array}{c}\text { Koefisien } \\
\text { korelasi } \\
(\text { zero })\end{array}$ & $\begin{array}{c}\text { Second order } \\
\text { correlation }\end{array}$ & $\mathbf{t}_{\text {hitung }}$ & \multicolumn{2}{|c|}{$\mathbf{t}_{\text {tabel }}$} \\
\cline { 5 - 6 } & 0,347 & 0,235 & $3,38^{* *}$ & 1,98 & 2,63 \\
\hline 85 & 0,05 & $\mathbf{0 , 0 1}$ \\
\hline
\end{tabular}

$* * \mathrm{p}<0,01$

Adapun koefisien determinasi hubungan antara conscientiousness dengan employee's environmental performance, pada second order correlation sebesar $(0,235)^{2}$ x $100 \%$ berarti $5,52 \%$ variasi dalam employee's environmental performance dapat dijelaskan dengan conscientiousness.

Hasil uji kekuatan koefien korelasi parsial yang mendekripsikan hubungan antara conscientiousness dengan employee's environmental performance, jika agreeableness, neuroticism, openness, dan extraversion dikontrol menghasilkan koefisien $\mathrm{r}_{\mathrm{y} 1.2345}=$ $0,235<\mathrm{t}_{(0,01)(85)}=2,63$; maka $\mathrm{t}_{\text {hitung }}>\mathrm{t}_{\text {tabel }}$. Artinya walaupun agreeableness, neuroticism, openness, dan extraversion dikontrol dari hubungan antara conscientiousness dengan employee's environmental performance tetap positif dan sangat signifikan (Tabel 2).

Keberhasilan kinerja suatu perusahaan ditentukan oleh conscientiousness atau kesungguhan karyawan dari suatu perusahaan berupa kecenderungan karyawan yang bertanggung jawab dan dapat diandalkan di perusahaan. Conscientiousness pada penelitian ini meliputi dapat diandalkan, suka berorganisasi, dapat dipercaya, ambisius, pekerja keras dan tekun.

Adapun dasar acuan teoretik yang digunakan dalam menjelaskan variabel yang mempengaruhi kinerja seperti conscientiousness menggunakan payung 
teori Integrative Model of Organizational Behavior dari Colquitt, et. al., (2017:294307) dan menggunakan payung teori Model Perilaku Bertanggung Jawab terhadap Lingkungan yang telah diadaptasi oleh Blaikie \& Ward (1993) dari Model Hinnes et al (1986/1987).

\section{Hubungan antara Agreeableness Dengan Employee's Environmental Performance}

Hubungan antara agreeableness dengan employee's environmental performance dianalisis dengan regresi sederhana. Hasil analisis regresi korelasi didapatkan persamaan $\hat{\mathrm{Y}}=105,884+$ $0,943 X_{2}$.

Tabel 3.

ANAVA untuk Uji Signifikasi dan Linearitas Model Regresi $\hat{Y}=105,884+0,943 X_{2}$

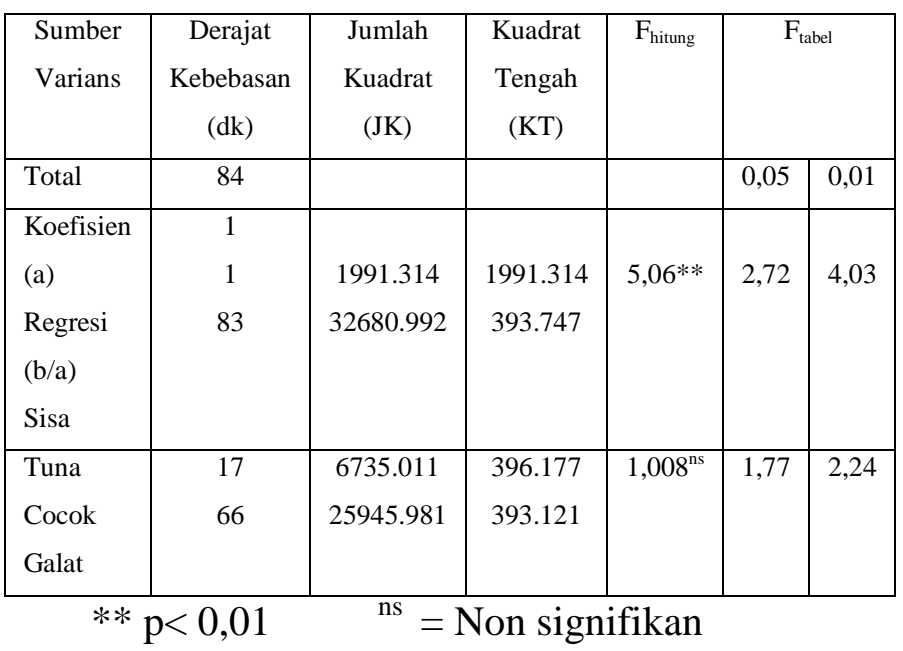

Pada tabel di atas menunjukkan ada hubungan yang sangat sigifikan antara agreeableness dengan employee's environmental performance. hubungan tersebut ( regresi $\hat{Y}=105,884+0,943 \mathrm{X}_{2}$ ) adalah linier. Koefisien korelasi antara agreeableness dengan employee's environmental performance $\left(\mathrm{r}_{\mathrm{y} 2}\right)$ sebesar $0,240<\mathrm{t}$ tab $(2,25)$

Artinya semakin tinggi agreeableness maka employee's environmental performance juga akan mengikutinya menjadi semakin tinggi pula (tabel 4)

Tabel 4.

Uji Keberartian Koefisien Korelasi Parsial ( $\mathrm{r}_{\mathrm{y} 2.1345)}$

\begin{tabular}{|c|c|c|c|c|c|}
\hline \multirow{2}{*}{$\begin{array}{c}\text { Sampel } \\
\text { (n) }\end{array}$} & \multirow{2}{*}{$\begin{array}{c}\text { Koefisien } \\
\text { korelasi } \\
\text { (zero })\end{array}$} & \multirow{2}{*}{$\begin{array}{c}\text { Second } \\
\text { order } \\
\text { correlation }\end{array}$} & \multirow[t]{2}{*}{$\mathrm{t}_{\text {hitung }}$} & \multicolumn{2}{|c|}{$\mathrm{t}_{\text {tabel }}$} \\
\hline & & & & 0,05 & 0,01 \\
\hline 85 & 0,240 & 0,142 & $\begin{array}{c}2,25^{*} \\
*\end{array}$ & 1,98 & 2,63 \\
\hline
\end{tabular}

Adapun koefisien determinasi hubungan antara agreeableness dengan employee's environmental performance, pada second order correlation sebesar $(0,142)^{2} \times 100 \%$ berarti $2,2 \%$ variansi dalam employee's environmental performance dapat dijelaskan dengan agreeableness.

Hasil uji kekuatan koefisien korelasi parsial yang mendekripsikan hubungan antara agreeableness dengan employee's environmental performance, jika conscientiousness, neuroticism, openness, dan extraversion dikontrol menghasilkan koefisien $r_{\mathrm{y} 2.1345}=0,142<$ $t_{(0,01)(85)}=2,63$; maka $t_{\text {hitung }}>t_{\text {tabel. }}$. Artinya walaupun conscientiousness, neuroticism, 
openness, dan extraversion dikontrol dari hubungan antara agreeableness dengan employee's environmental performance tetap positif dan signifikan.

Keberhasilan kerja dari suatu perusahaan ditentukan oleh agreeablesness (keramahan) karyawan suatu perusahaan.

Adapun dasar acuan teoretik yang digunakan dalam menjelaskan variabelvariabel yang mempengaruhi kinerja seperti agreeablesness Adapun dasar acuan teoretik yang digunakan dalam menjelaskan variabel yang mempengaruhi kinerja seperti conscientiousness menggunakan payung teori Integrative Model of Organizational Behavior dari Colquitt, et.al., (2009: 34).

Sedangkan menurut Ivancevich, Konopaske \& Matteson (2014:75) mengatakan, "Agreeableness it is the tendency to be courteous, forgiving, tolerant, trusting, and softhearted." Keramahan adalah kecenderungan seseorang untuk memiliki rasa hormat, pemaaf, toleran, mudah percaya, dan berhati lunak. Menurut Luthans (2014:77), "ciri utama keramahan adalah kooperatif, hangat, perhatian, sopan, dan dapat dipercaya." Suka bekerja sama, simpatik, suka menolong, santun, dan hangat adalah kepribadian yang agreebleness.

\section{Hubungan antara Neuroticism Dengan Employee's Environmental Performance}

Hubungan antara neuroticism dengan employee's environmental performance dianalisis dengan regresi sederhana. Hasil analisis tersebut mendapatkan persamaan $\hat{\mathrm{Y}}=97,504+$ $0,310 X_{3}$. Adapun untuk uji signifikan dan linieritas model regresi terdapat pada tabel 5 berikut ini:

Tabel 5.

ANAVA untuk Uji Signifikasi dan Linearitas Model Regresi $\hat{Y}=97,504+0,310 X_{3}$

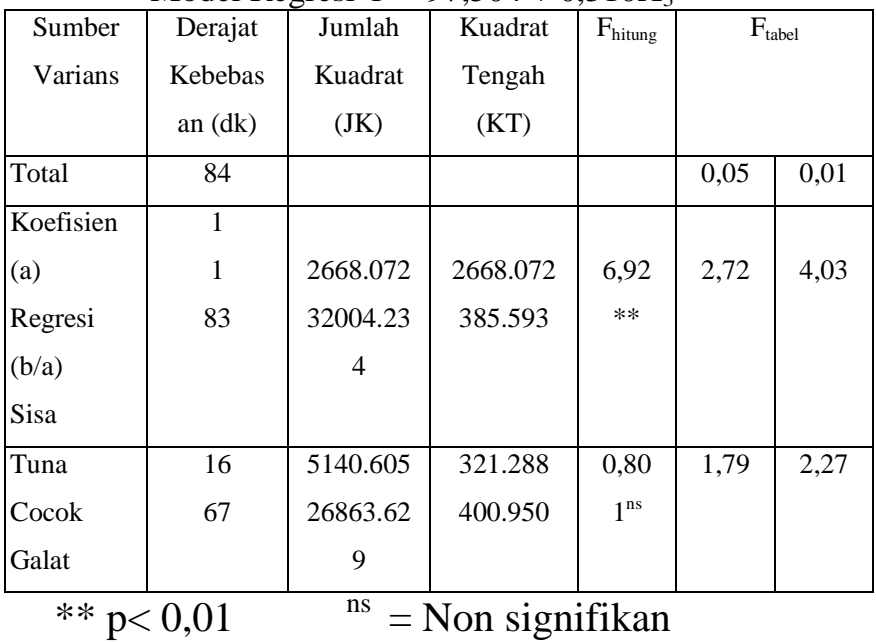

Pada tabel di atas menunjukkan ada hubungan yang sangat signifikan antara neuroticism dengan employee's, environmental performance. Hubungan tersebut (regresi $\hat{Y}=97,504+$ $\left.0,310 X_{3}\right)$ adalah linier. Artinya dapat diinterpretasikan setiap perubahan skor neuroticism sebesar 1 point dapat diperkirakan skor employee's environmental performance juga akan berubah sebesar 0,310 pada arah yang 
sama dengan konstanta sebesar sebesar 97,504. Koefisien korelasi antara neuroticism dengan employee's environmental performance $\left(\mathrm{r}_{\mathrm{y} 3}\right)$ sebesar 0,277 .

Hasil uji t untuk $\mathrm{t}_{\text {hitung }}>\mathrm{t}_{\text {tabel }} \alpha=$ 0,05 atau 2,63 > 1,98. Berarti koefisien korelasi antara neuroticism dengan employee's environmental performance signifikan. Hasil penelitian adalah terdapat hubungan positif yang signifikan antara neuroticism dengan employee's environmental performance. Artinya semakin tinggi neuroticism maka employee's environmental performance juga akan semakin tinggi.

Hasil pengujian pada tabel 6 di bawah ini:

Tabel 6.

Uji Keberartian Koefisien Korelasi Parsial $\left(\mathrm{r}_{\mathrm{y} 3.1245}\right)$

\begin{tabular}{|c|c|c|c|c|c|}
\hline $\begin{array}{c}\text { Sampel } \\
(\mathrm{n})\end{array}$ & $\begin{array}{c}\text { Koefisien } \\
\text { korelasi } \\
(\text { zero })\end{array}$ & $\begin{array}{c}\text { Second } \\
\text { order } \\
\text { correlation }\end{array}$ & $\mathrm{t}_{\text {hitung }}$ & \multicolumn{2}{|c|}{$\mathrm{t}_{\text {tabel }}$} \\
\cline { 5 - 6 } & & 0,05 & 0,01 \\
\hline 85 & 0,277 & 0,145 & $2,63^{* *}$ & 1,98 & 2,63 \\
\hline
\end{tabular}

$* * \mathrm{p}<0,01$

Adapun koefisien determinasi hubungan antara neuroticism dengan employee's environmental performance, pada second order correlation sebesar $(0,145)^{2} \times 100 \%$ berarti $2,1 \%$ variasi dalam employee's environmental performance dapat dijelaskan dengan neuroticism.
Hasil uji kekuatan koefien korelasi parsial yang mendekripsikan hubungan antara neuroticism dengan employee's environmental performance, jika conscientiousness, agreeableness, openness, dan extraversion dikontrol hasilnya adalah koefisien $\mathrm{r}_{\mathrm{y} 3.1245}=0,145<$ $t_{(0,05)(85)}=1,98$; maka $t_{\text {hitung }}>t_{\text {tabel }}$. Artinya walaupun conscientiousness, agreeableness, openness, dan extraversion dikontrol dari hubungan antara neuroticism dengan employee's environmental performance namun tetap positif dan signifikan.

Keberhasilan kinerja dari suatu perusahaan ditentukan oleh neuroticism karyawannya. Neuroticism (stabilitas emosi) merupakan kecenderungan seseorang mengalami emosi positif yang tenang, santai dan aman. Neuroticism pada penelitian ini meliputi gugup, suka murung, emosional, gelisah, hati-hati, mudah tersinggung.

Bakker, Tims dan Derks (2012: 1360-1361), menyatakan bahwa beberapa penelitian telah mengungkapkan bahwa kepribadian positif pada karyawan menunjukkan kinerja pekerjaan yang baik pula, karena dampak lingkungan di perusahaan yang positif tersebut memfasilitasi keterlibatan pekerjaan hasil kepribadian tersebut.Karenanya manajemen dapat mempengaruhi 
pekerjaan karyawan dan sumber daya yang dihasilkan. Sangat penting bagi karyawan untuk menunjukkan perilaku proaktif dan mengoptimalkan lingkungan kerja mereka sendiri.

\section{Hubungan antara openness dengan employee's environmental performance}

Hubungan antara openness dengan employee's environmental performance dianalisis dengan regresi sederhana. Hasil analisis tersebut mendapatkan persamaan $\hat{Y}=93,843+0,270 X_{4}$. Adapun uji signifikansi dan linieritas terdapat pada tabel 7 berikut ini:

Tabel 7.

ANAVA untuk Uji Signifikansi dan Linearitas Model Regresi $\hat{Y}=93,843+0,270 X_{4}$

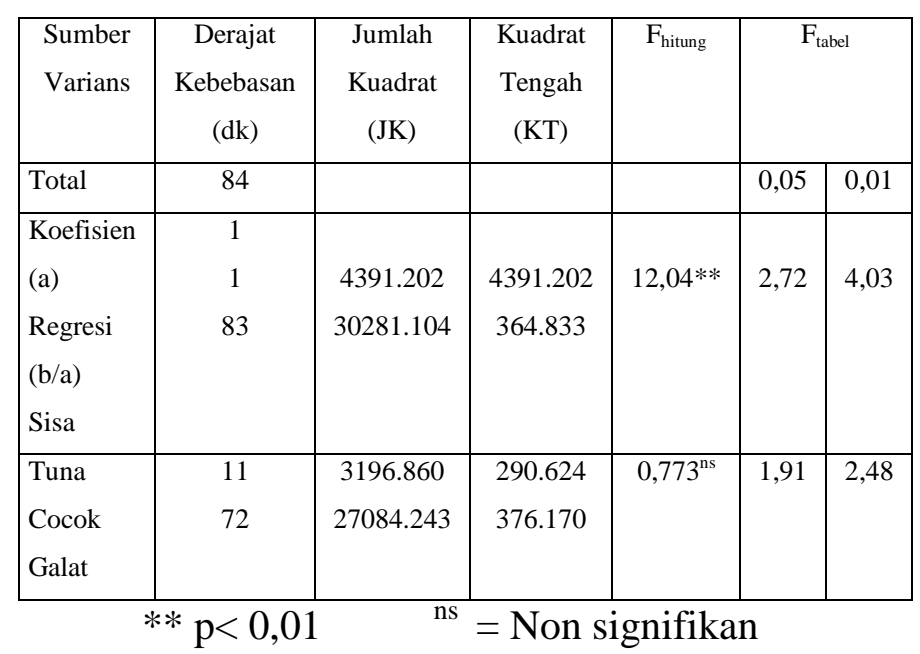

Pada tabel di atas terlihat ada hubungan yang sangat signifikan antara openness dengan employee's, environmental performance. Hubungan tersebut (regresi $\hat{\mathrm{Y}}=93,843+0,270 \mathrm{X}_{4}$ ) adalah linier.

Artinya setiap perubahan skor openness sebesar 1 point dapat diperkirakan skor employee's environmental performance juga akan berubah sebesar 0,270 pada arah yang sama dengan konstanta sebesar sebesar 93,843. Koefisien korelasi antara openness dengan employee's environmental performance $\left(\mathrm{r}_{\mathrm{y} 4}\right)$ sebesar 0,356. Adapun untuk uji keberartian korelasi terdapat pada tabel 8 berikut ini:

Tabel 8.

Uji Keberartian Koefisien Korelasi Parsial ( $\mathrm{r}_{\mathrm{y} 4.1235)}$

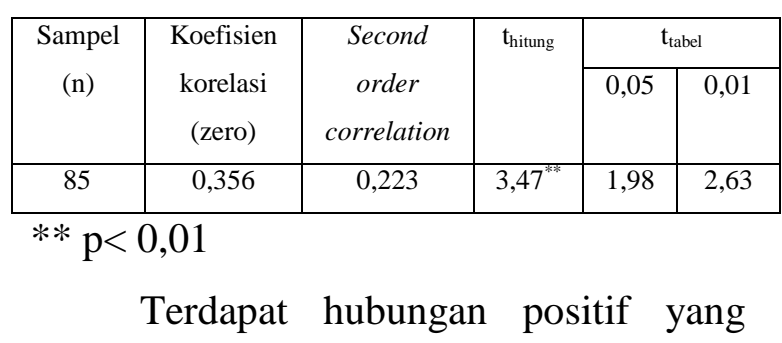
sangat signifikan antara openness dengan employee's environmental performance. semakin tinggi openness maka employee's environmental performance juga akan semakin tinggi.

Adapun koefisien determinasi hubungan antara openness dengan employee's environmental performance, pada second order correlation sebesar $(0,223)^{2} \times 100 \%$ berarti $4,97 \%$ variasi dalam employee's environmental 
performance dapat dijelaskan dengan openness.

Hasil uji kekuatan koefien korelasi parsial yang mendekripsikan hubungan antara openness dengan employee's environmental performance, jika conscientiousness, agreeableness, neuroticism, dan extraversion dikontrol hasilnya adalah koefisien $r_{\mathrm{y} 4.1235}=0,223$ dan $t_{\text {hitung }}=3,47$; dan $t_{(0,05)(85)}=1,98$; maka $t_{\text {hitung }}>t_{\text {tabel }}$. Artinya walaupun conscientiousness, agreeableness, neuroticism, dan extraversion dikontrol dari hubungan antara openness dengan employee's environmental performance tetap positif dan signifikan.

Keberhasilan kerja dari suatu perusahaan ditentukan oleh openness (keterbukaan) karyawan suatu perusahaan. Openness merupakan kecenderungan seseorang untuk merefleksikan sejauh mana individu memiliki minat yang luas terhadap hal-hal yang baru. Openness pada penelitian ini meliputi ingin tahu, kreatif, sopan, dan jelimet/sukar.

Berdasarkan pendapat Ivancevich, Konopaske \& Matteson (2014:75) bahwa, "Opennes to experience this dimension reflects the extent to which an individual has broad interests and is willing to take risks." Keterbukaan terhadap pengalaman adalah kecenderungan individu untuk merefleksikan sejauh mana individu memiliki minat yang luas dan bersedia mengambil resiko. Sikap yang muncul adalah rasa ingin tahu, pemikiran terbuka, kreativitas, imajinasi,dan terintegrasi.

Kinerja lingkungan menurut Paile, Chen, Boiral dan Jin (2013:1-5) didefinisikan sebagai efektivitas perusahaan dalam memenuhi dan melebihi harapan masyarakat terhadap keprihatinan untuk lingkungan alam. Kinerja lingkungan sendiri dapat dievaluasi dengan menetapkan indikator seperti pencegahan polusi, minimalisasi limbah, kegiatan daur ulang, dan lain sebagainya.

\section{Hubungan antara Extraversion Dengan} Employee's Environmental Performance

Hubungan antara extraversion dengan employee's environmental performance dianalisis dengan regresi sederhana. Hasil analisis tersebut mendapatkan persamaan $\hat{\mathrm{Y}}=93,817+$ $0,954 X_{5}$

Tabel 9.

ANAVA untuk Uji Signifikasi dan Linearitas Model Regresi $\hat{Y}=93,817+0,954 X_{5}$

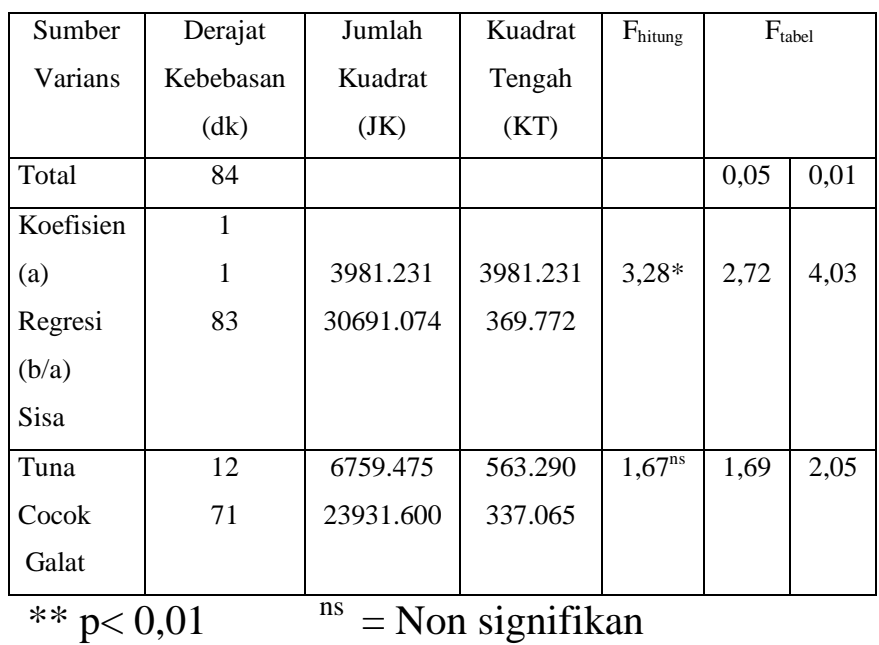


Pada tabel di atas menunjukkan ada hubungan yang positif dan signifikan antara extraversion dengan employee's, environmental performance. Hubungan tersebut (regresi $\hat{Y}=93,817+0,954 X_{5}$ ) adalah linier. Artinya setiap perubahan skor extraversion sebesar 1 point dapat diperkirakan skor employee's environmental performance juga akan berubah sebesar 0,954 pada arah yang sama dengan konstanta sebesar sebesar 93,817 .

Koefisien korelasi antara extraversion dengan employee's environmental performance $\left(\mathrm{r}_{\mathrm{y} 5}\right)$ sebesar 0,339 . Hasil pengujian pada tabel $10 \mathrm{di}$ bawah ini:

Tabel 10.

Uji Keberartian Koefisien Korelasi Parsial $\left(\mathrm{r}_{\mathrm{y} 5.1234}\right)$

\begin{tabular}{l}
\begin{tabular}{l|c|l|l|l|l|}
\hline $\begin{array}{c}\text { Sampel } \\
(\mathrm{n})\end{array}$ & $\begin{array}{c}\text { Koefisien } \\
\text { korelasi } \\
(\text { zero })\end{array}$ & $\begin{array}{c}\text { Second } \\
\text { order } \\
\text { correlation }\end{array}$ & $\mathrm{t}_{\text {hitung }}$ & \multicolumn{2}{|c|}{$\mathrm{t}_{\text {tabel }}$} \\
\cline { 5 - 6 } & 0,339 & 0,260 & $3,28^{* *}$ & 1,98 & 2,63 \\
\hline 85 & 0,05 & 0,01 \\
$* * \mathrm{p}<0,01$
\end{tabular} \\
\hline
\end{tabular}

Hasil uji $\mathrm{t}$ untuk $\mathrm{t}_{\text {hitung }}>\mathrm{t}_{\text {tabel }} \alpha=$ 0,01 atau 3,28 > 2,63. Berarti koefisien korelasi antara extraversion dengan employee's environmental performance signifikan. Artinya terdapat hubungan positif yang signifikan antara extraversion dengan employee's environmental performance, semakin tinggi extraversion maka employee's environmental performance juga akan semakin tinggi.
Adapun koefisien determinasi hubungan antara extraversion dengan employee's environmental performance, pada second order correlation sebesar $(0,260)^{2} \times 100 \%$ berarti $6,76 \%$ variasi dalam employee's environmental performance dapat dijelaskan dengan extraversion.

Hasil uji kekuatan koefien korelasi parsial. adalah $r_{\mathrm{y} 5.1234}=0,260$ dan $t_{\text {hitung }}=$ 3,28 ; sedangkan $\mathrm{t}_{(0,05)(85)}=1,98 ; \mathrm{t}_{\text {hitung }}>$ $\mathrm{t}_{\text {tabel. }}$ Artinya walaupun conscientiousness, agreeableness, neuroticism, dan openness dikontrol dari hubungan antara extraversion dengan employee's environmental performance tetap positif dan signifikan.

Keberhasilan kerja dari suatu perusahaan ditentukan oleh extraversion (bersosialisasi) karyawan suatu perusahaan. Extraversion merupakan kepribadian yang cenderung positif dan selalu terbuka pada hal-hal yang baru baik dalam perilaku dan pengetahuan. Extraversion pada penelitian ini meliputi banyak bicara, suka bergaul, penuh gairah, tegas, dan berani mengungkapkan kebenaran.

Penelitian yang dilakukan oleh Brandstatter (2011:223), hasil penelitiannya: dalam arti luas, ciri-ciri kepribadian mencakup kemampuan (misalnya, umum intelijen serta numerik, 
verbal, spasial, atau emosional intelijen), motif (misalnya, kebutuhan untuk berprestasi, kekuasaan, atau afiliasi), sikap (termasuk nilai-nilai), dan karakteristik temperamen sebagai gaya menyeluruh dari pengalaman seseorang dan tindakan (Keterbukaan terhadap pengalaman, kesadaran, Extraversion, Keramahan, dan Neuroticism).

Bakker, Tims dan Derks (2012: 1360-1361), menyatakan bahwa beberapa penelitian telah mengungkapkan bahwa kepribadian positif pada karyawan menunjukkan kinerja pekerjaan yang baik pula. Dimana, karena dampak lingkungan di perusahaan yang positif tersebut memfasilitasi keterlibatan pekerjaan dari hasil kepribadian tersebut. Karenanya pihak manajemen dapat mempengaruhi pekerjaan dari karyawan dan sumber daya yang dihasilkan. Sangat penting bagi karyawan untuk menunjukkan perilaku proaktif dan mengoptimalkan lingkungan kerja mereka sendiri.

Hubungan antara Conscientiousness, Agreeableness, Neuroticism, Openness Dan Extraversion Secara BersamaSama Dengan Employee's Environmental Performance

Hasil analisis tersebut mendapatkan persamaan $\hat{\mathrm{Y}}=88,855+$ $0,196 X_{1}+0,031 X_{2}+0,591 X_{3}+0,724 X_{4}+$ $0,223 \mathrm{X}_{5}$. Untuk hasil pengujian keberartian dan linearitas regresi disajikan pada Tabel 11 di bawah ini:

Tabel 11.

ANAVA untuk Regresi Jamak $\hat{\mathrm{Y}}=88,855+0,196 \mathrm{X}_{1}+0,031 \mathrm{X}_{2}+$ $0,591 X_{3}+0,724 X_{4}+0,223 X_{5}$

\begin{tabular}{|l|c|c|c|c|c|c|}
\hline \multicolumn{7}{|c|}{$0,591 \mathrm{X}_{3}+0,724 \mathrm{X}_{4}+0,223 \mathrm{X}_{5}$} \\
Varians & $\begin{array}{c}\text { Derajat } \\
\text { Kebebas } \\
\text { an (dk) }\end{array}$ & $\begin{array}{c}\text { Jumlah } \\
\text { Kuadrat } \\
(\mathrm{JK})\end{array}$ & $\begin{array}{c}\text { Kuadrat } \\
\text { Tengah } \\
(\mathrm{KT})\end{array}$ & $\begin{array}{c}\mathrm{F}_{\text {hitun }} \\
\mathrm{g}\end{array}$ & \multicolumn{2}{|c|}{$\mathrm{F}_{\text {tabel }}$} \\
\hline Total & 84 & & & & 0,05 & 0,01 \\
Direduksi & 5 & 7032.212 & 1406.442 & 4,02 & 2,33 & 3,26 \\
\hline Regresi & 79 & 27640.09 & 349.875 & $* *$ & & \\
Sisa & 3 & & & & \\
\hline
\end{tabular}

Pada tabel di atas hasil pengujian signifikansi koefisien regresi secara keseluruhan yaitu $F_{\text {hitung }} 4,02>F_{\text {tabel }} \alpha=$ 0,05 dan 0,01, maka persamaan regresi tersebut sangat signifikan.

Analisis terhadap korelasi jamak antara conscientiousness, agreeableness, neuroticism, openness dan extraversion secara bersama-sama dengan employee's environmental performance menghasikan koefisien korelasi jamak $\left(\mathrm{R}_{\mathrm{y} 12345}\right)$ sebesar 0,450; disajikan pada tabel 12 di bawah ini:

Tabel 12.

Uji Keberartian Korelasi Jamak $\left(\mathrm{R}_{\mathrm{y} 12345}\right)$

\begin{tabular}{c|c|c|c|c|c|c|}
\hline $\begin{array}{c}\text { Sampel } \\
(\mathrm{n})\end{array}$ & $\begin{array}{c}\text { Koefisien } \\
\text { korelasi } \\
(\text { zero })\end{array}$ & $\begin{array}{c}\text { Second } \\
\text { order } \\
\text { correlation }\end{array}$ & $\mathrm{F}_{\text {hitung }}$ & \multicolumn{2}{|c|}{$\mathrm{F}_{\text {tabel }}$} \\
\cline { 4 - 6 } & 0,450 & 0,203 & $4,02^{* *}$ & 2,33 & 3,26 & 0,01 \\
\hline 85 & & & & \\
\hline$* * \mathrm{p}<0,01$
\end{tabular}

Hasil penelitian adalah terdapat hubungan positif yang sangat signifikan, antara conscientiousness, agreeableness, 
neuroticism, openness dan extraversion secara bersama-sama dengan employee's environmental performance. $\quad(\mathrm{p}<0,01)$ Artinya semakin baik conscientiousness, agreeableness, neuroticism, openness dan extraversion maka semakin baik pula employee's environmental performance.

Koefisien determinasi hubungan tersebut pada second order correlation sebesar $(0,203)^{2}$ x $100 \%$ berarti $4,12 \%$. Hal ini menunjukkan 4,12\% variasi dalam employee's environmental performance dapat dijelaskan oleh conscientiousness, agreeableness, neuroticism, openness dan extraversion secara bersama-sama. Dapat diartikan pula hubungan berbanding lurus antara conscientiousness, agreeableness, neuroticism, openness dan extraversion secara bersama-sama dengan employee's environmental performance sebesar 0,450 melalui model regresi $\hat{Y}=88,855+$ $0,196 X_{1}+0,031 X_{2}+0,591 X_{3}+0,724 X_{4}+$ $0,223 X_{5}$.

Bakker, Tims dan Derks (2012:1360-1361), menyatakan bahwa beberapa penelitian telah mengungkapkan bahwa kepribadian positif pada karyawan menunjukkan kinerja pekerjaan yang baik pula. Dimana, karena dampak lingkungan di perusahaan yang positif tersebut memfasilitasi keterlibatan pekerjaan dari hasil kepribadian tersebut. Karenanya pihak manajemen dapat mempengaruhi pekerjaan dari karyawan dan sumber daya yang dihasilkan. Sangat penting bagi karyawan untuk menunjukkan perilaku proaktif dan mengoptimalkan lingkungan kerja mereka sendiri.

Kinerja lingkungan menurut Paile, Chen, Boiral dan Jin (2013:1-5) didefinisikan sebagai efektivitas perusahaan dalam memenuhi dan melebihi harapan masyarakat terhadap keprihatinan untuk lingkungan alam.

\section{KESIMPULAN}

Berdasarkan temuan tersebut maka dapat disimpulkan, apabila ingin ditingkatkan employee's environmental performance, maka faktor-faktor personality seperti conscientiousness, agreeableness, neuroticism, openness dan extraversion juga perlu ditingkatkan.

\section{DAFTAR PUSTAKA}

Ahmad, A. d. 2009. Organizational Behavior Improving Performance in The Work Place. New York: McGraw-Hill, Inc.

Ahmad, J. M. 2014. Impact of Big Five Personality Traits on Job Performance: Organizational Commitment as A Mediator.

Bakker, A. B. 2012. Proactive Personality and Job Performance: The Role of Job Crafting and Work 
Engagement. Journal of Human Relations.

Boiral, O. C. (2014). Environmental Leadership and Counsciousness Development: A Case Study Among Canadian SMEs. Journal Business Ethics.

Brandstatter, H. (2011). Personality Aspects of Entrepreneurship: A Look at Five Meta Analyses. Journal of Personality and Individual Differences.

Colquitt, J A., Jeffrey A. LePine \& Michael J. Wesston, Organizational Behavior: Improving Performance and Commitment in the Workplace 4th Edition

Ivancevich, J. M. 2014. Organizational Behavior \& Management. New York: McGraw-Hill Education.

Jing Zhang, J. N. (2014). A multilevel analysis of effects of land use policy on land-cover change and local land use decisions. Journal of Arid Environments.

Luthans, F. 2008. Organizational Behavior Eleventh Edition. Singapore: McGraw-Hill International Edition.

Paile, P. Y. (2013). The Impact of Human Resource Management on Environmental Performance: An Employee Level Study. Journal of Business Ethics.

Yang Chen, G. T. (2015). The Influence of Environmental Strategy, Employee's Environmental Involvement , Environmental Product Quality. Journal of Business EthicLinking Market Orientation and Environmental Performance. 